\title{
AZ ALÁMETSZÉS KÖRÜLMÉNYEI LEKEREKÍTETT GYÁRTÓ FOGASLÉC ESETÉBEN
}

\section{THE CONDITIONS OF UNDERCUT BY SHAPING USING A ROUNDED PROFILE GEAR SHAPER CUTTER}

\author{
Hodgyai Norbert, ${ }^{1}$ Tolvaly-Roșca Ferenc, ${ }^{2}$ Máté Márton ${ }^{3}$ \\ ${ }^{1}$ Sapientia EMTE, Marosvásárhelyi Kar, Gépészmérnöki Tanszék, Kolozsvár, Románia, \\ hodgyai@ms.sapientia.ro \\ 2 Sapientia EMTE, Marosvásárhelyi Kar, Gépészmérnöki Tanszék, Kolozsvár, Románia, \\ tferi@ms.sapientia.ro \\ ${ }^{3}$ Sapientia EMTE, Marosvásárhelyi Kar, Gépészmérnöki Tanszék, Kolozsvár, Románia, \\ mmate@ms.sapientia.ro
}

\begin{abstract}
The present paper deals with the cases of undercut when not only the linear but the curved segment of the generatrix curve is also taken in consideration. The literature admits the approximation of the root fillet with a circular arc with a radius of $0,38 \mathrm{~m}$. In this paper, instead of this approximation, the real envelope realized by the rounded rack-head is computed. In analyzing the undercut there are two classical synthetic geometrical models supporting Litvin's general equations that describe the condition of avoiding the undercut: one for the linear and one for the rounded part of the generatrix. The scope of exact computing of the root fillet curve consists in optimizing the cutting toll tooth topland geometry to obtain the best rigidity. The numerically evaluated models allow us to conclude that profile shifting can be pushed below the undercut limits stated in the classical literature, without the appearance of the well-known fracture point on the meshed tooth profile.
\end{abstract}

Keywords: rack, profile parameters, meshing, root fillet, undercut.

\section{Összefoglalás}

Jelen közlemény az alámetszés sajátos eseteit vizsgálja akkor, amikor a lécprofilnak nemcsak az egyenes, hanem a lekerekített szakaszát is generáló profilnak tekinti. A szakirodalomban elterjedt 0,38 m sugarú csatlakoztatási körív helyett a fogfej lekerekített része által burkolt valós foglábgörbét tekinti. A Litvin által megfogalmazott alámetszési általános analitikus feltételek helyett két alternatív, egyszerübb matematikai kifejezéseket kínáló szintetikus geometriai modellt mutat be, külön az egyenes és külön a lekerekített generáló görbe szakaszra. A fogláb pontos alakmeghatározásának az a célja, hogy a szerszám fogfejének megfelelő kialakításával a fogtőszilárdságot, és ennek következtében a terhelhetőséget növelhessük. A numerikusan kiértékelt modellek arra engednek következtetni, hogy a klasszikus irodalomban fellelhető alámetszés határa alá is lehet fogazni, anélkül, hogy a teljes burkolón létrejönne a jellegzetes töréspont.

Kulcsszavak: léc, profilparaméterek, burkolás, foglábgörbe, alámetszés.

\section{A foglábgörbe jelentősége}

A kapcsolódó fogazatok pontos geometriájának analitikus és szintetikus, numerikus vagy vegyes vizsgálati módszereit sokan kutatták-alkalmazták [1, 2, 3, 4]. A fogaskerék fogtőgörbéjét a legtöbben körívvel közelítik [4, 5, 6], és szimulációs vizsgálatok során sem tekintenek el ettől. A foglábgörbe alakja, kialakításának pontossága, a felület finomsága határozott befolyást gyakorol a fogazat élettartamára, a teherbírására és nem utolsósorban a hajtás rezgésképére. 
A fogaskerék foglábfelületének és müködő fogfelületének kapcsolódását viszonylag egyszerűen tárgyalja a szakirodalom. A talpkör pontos definícióját és sugarának számítását először Szeniczei publikálja [7], arra az esetre, amikor a lécprofil aktív fejvonala határozza meg a talpkör sugarát. A foglábgörbét arra az esetre írja fel, amikor azt a generáló szerszámél és a fejszalagél metszéspontja írja le: hurkolt evolvens gyártóléc, hurkolt epiciklois metszőkerék esetében.

Litvin [2] ennél pontosabban határozza meg a foglábgörbét, állítván, hogy a lekerekítési ív középpontja által a relatív mozgás során leírt hurkolt evolvenstől vagy cikloistól lekerekítési sugárnyi távolságra illeszkedő görbe.

$\mathrm{Az}$ eddig elért eredmények alapján több kérdés fogalmazható meg. Az első a foglábgörbe és a hasznos fogprofil kapcsolódási helyének változása a profileltolással. Lényeges az alámetszés geometriájának összehasonlítása a klasszikus átmetszési geometriával. Végül, hogy a szerszám éllekerekítésének alakja miként befolyásolja a kialakuló foglábgörbét, és ennek milyen hatása van a fogtő szilárdságára és merevségére.

A következőkben a körív lekerekítésű gyártóléc és a kialakított teljes fogoldalprofil összefüggéseit vizsgáljuk.

\section{A gyártóléc paraméterei}

Jelen tanulmányban a DIN 867-1986-os alapprofilból származtatott gyártólécet tekintjük. A szabvány a foglábmagasságot $h_{P} \in(1,1 \div 1,4) m$ között definiálja. A gyártóléc vizsgálatát a $h_{P}=1,25 \mathrm{~m}$ értékre végezzük el.

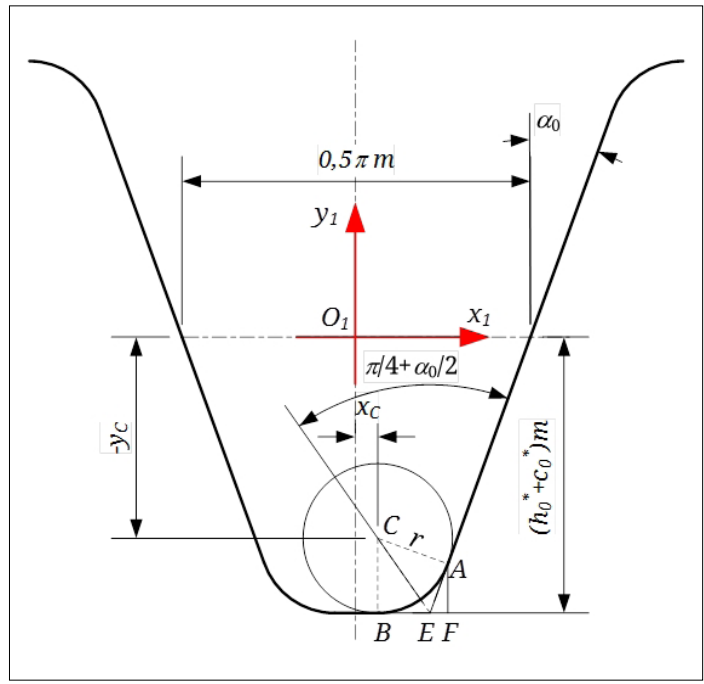

1. ábra. A generáló fogasléc lekerekített profilja
Tekintsük az 1. ábrán definiált fogaslécprofilt. A lekerekítési sugarat két feltételből lehet kiszámítani: az első az, hogy a fogfej éle a két körív találkozásából alakuljon ki; a másik pedig az, hogy a körív a fog magasságából legtöbb $c_{0}^{*} m$ részt foglaljon le. Kiindulván ebből a feltételezésből, az 1.ábra alapján felírhatjuk, hogy

$$
r=\frac{m c_{0}^{*}}{\cos \alpha_{0}} \operatorname{tg}\left(\frac{\alpha_{0}}{2}+\frac{\pi}{4}\right)
$$

Ezzel az értékkel kiszámítjuk az EB szakasz hoszszát:

$$
E B=E A=\frac{m c_{0}^{*}}{\cos \alpha_{0}}
$$

Ezt az értéket összehasonlítjuk az elméleti lekerekítetlen fogfejérték felével, és kiszámítjuk a különbséget:

$$
\delta=\frac{\pi m}{4}-m\left(h_{0}^{*}+c_{0}^{*}\right) \operatorname{tg} \alpha_{0}-\frac{m c_{0}^{*}}{\cos \alpha_{0}}
$$

A szabványos fogasléc paraméterértékekre $\delta>0$, tehát a fejél két szimmetrikus körívből és az ezeket összekötő vízszintes érintőből áll. A fejél folytonos, nincs átmetszés.

Az (1) képlettel kiszámított sugár a legnagyobb lehetséges érték, bevezetjük az $\psi$ redukáló tényezőt, $\psi \in[0,1]$, ezzel pedig a lekerekítési sugár értékét a következőképpen számítjuk:

$$
r=\psi r^{*} m=\psi \frac{c_{0}^{*}}{\cos \alpha_{0}} \operatorname{tg}\left(\frac{\alpha_{0}}{2}+\frac{\pi}{4}\right) m
$$

Ha az $r$ sugár értékét kijelöltük, akkor kiszámíthatók a $C$ központ koordinátái (1. ábra):

$$
\left\{\begin{array}{l}
x_{1}^{C}=m\left(\frac{\pi}{4}-\left(h_{0}^{*}+c_{0}^{*}\right) \operatorname{tg} \alpha_{0}-\frac{\psi r^{*}}{\cos \alpha_{0}}\right) \\
y_{1}^{C}=\left(\psi r^{*}-\left(h_{0}^{*}+c_{0}^{*}\right)\right) m
\end{array}\right.
$$

\section{Az alkalmazott koordináta-rendsze- rek}

A szerszám-fogaskerék relatív kinematikáját a 2. ábrán feltüntetett három koordináta-rendszer relatív helyzete segítségével írjuk fel.

A kapcsolódás főpontjában ered az állványhoz rögzített $O x_{0} y_{0}$ koordináta-rendszer. A gyártóléchez kötött az $O_{1} x_{1} y_{1}$ koordináta-rendszer, melynek $x_{1}$ tengelye a fogasléc osztóvonalára illeszkedik. A kerék centroidája az $x_{0}$ tengelyre illeszkedik. Végül, a fogazandó kerékhez kötött koordináta-rendszer az $\mathrm{O}_{2} x_{2} y_{2}$, melynek $\varphi$ elfordulási szöge határozza meg a léc $r_{0} \varphi x$-tengely menti elmozdulását [1].

A 2. ábra alapján, az [1, 2, 4, 8]-ben is alkalmazott módszerrel felírhatók a transzformáció-egyenletek: 


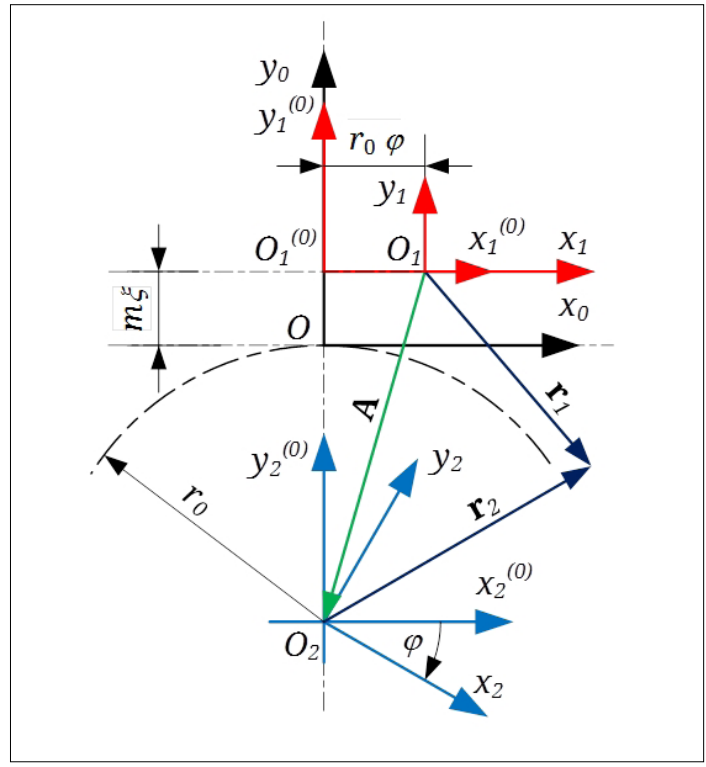

2. ábra. Az alkalmazott koordináta-rendszerek

$$
\underline{\boldsymbol{r}_{2}}=M_{21} \underline{\boldsymbol{r}_{1}}=\boldsymbol{M}_{20} \boldsymbol{M}_{01} \underline{\boldsymbol{r}_{1}}
$$

A 2. ábrán látható beállításnak megfelelően

$$
\boldsymbol{M}_{21}=\left(\begin{array}{ccc}
\cos \varphi & -\sin \varphi & a_{13}(\varphi) \\
\sin \varphi & \cos \varphi & a_{23}(\varphi) \\
0 & 0 & 1
\end{array}\right),
$$

$$
a_{13}(\varphi)=-r_{0}(\sin \varphi-\varphi \cos \varphi)+m \xi \sin \varphi
$$$$
a_{23}(\varphi)=r_{0}(\cos \varphi+\varphi \sin \varphi)+m \xi \cos \varphi
$$

\section{A kapcsolódási egyenlet}

A kapcsolódási egyenletet a [2] alapján írjuk fel. Az 1-es elem (gyártóléc) és a 2-es elem (fogazott kerék) közös pontjára mutató $\mathbf{r}_{1}$ és $\mathbf{r}_{2}$ helyvektorok, az 1-es rendszer origójából a 2-es rendszer origójára mutató A helyvektor segítségével, az 1-es koordináta-rendszerben felírható:

$$
\begin{aligned}
& \boldsymbol{v}_{1}^{(12)}=\boldsymbol{v}_{1}^{(1)}-\boldsymbol{v}_{1}^{(2)}= \\
= & \omega_{2} r_{0} \boldsymbol{i}_{1}-\boldsymbol{\omega}_{2} \times \boldsymbol{r}_{2}= \\
= & \omega_{2} r_{0} \boldsymbol{i}_{1}-\boldsymbol{\omega}_{2} \times\left(\boldsymbol{r}_{2}-\boldsymbol{A}\right)
\end{aligned}
$$

Az $\omega_{2}=1 \mathrm{rad} / \mathrm{s}$ szögsebességvektor-érték mellett, a számítások elvégzése után kapjuk:

$$
\underline{\boldsymbol{v}}_{1}^{12}=\left(\begin{array}{c}
-y_{1}-m \xi \\
x_{1}+r_{0} \varphi \\
0
\end{array}\right)
$$

\section{A teljes generáló görbe}

A teljes generáló görbe az egyenes, illetve a lekerekített szakaszból áll. Az egyenes szakaszt a fogmagasság mentén, a körívet pedig a központi szöggel parametrizáljuk:

$$
\begin{aligned}
& \left\{\begin{array}{c}
x_{1 e}(u)=\frac{\pi m}{4}+u \operatorname{tg} \alpha_{0} \\
y_{1 e}(u)=u
\end{array},\right. \\
& u \in\left[-\left(h_{0}^{*}+c_{0}^{*}\right), h_{0}^{*}\right] \\
& \left\{\begin{array}{l}
x_{1 k}(u)=x_{1}^{C}+r \cos \left(\alpha_{0}+u\right) \\
y_{1 k}(u)=y_{1}^{C}-r \sin \left(\alpha_{0}+u\right)
\end{array},\right. \\
& u \in\left[0, \frac{\pi}{2}-\alpha_{0}\right]
\end{aligned}
$$

A normálvektorok felírása azonnali, az 1. ábra alapján:

$$
\underline{\boldsymbol{n}}_{1 e}=\left(\begin{array}{c}
\cos \alpha_{0} \\
-\sin \alpha_{0} \\
0
\end{array}\right) ; \underline{\boldsymbol{n}}_{1 e}=\left(\begin{array}{c}
\cos \alpha_{0} \\
-\sin \alpha_{0} \\
0
\end{array}\right)
$$

\section{A kapcsolódási egyenlet megoldása}

A kapcsolódási egyenlet megoldását kizárólag a generálógörbe körívszakaszára írjuk fel - ismert tény, hogy az egyenes szakasz evolvenst fog burkolni. Ennek az evolvensnek a helyzetét a 2. ábrán látható beállítás betartása mellett - kiinduló, vagyis $\varphi=0$ helyzetben a főpont a generáló profil középvonalán illeszkedik - egyszerű geometriai levezetéssel [1, 7] megkaphatjuk:

$$
\begin{aligned}
& \left\{\begin{array}{l}
x_{2}^{e v}\left(\varphi_{1}\right)=r_{b}\left(\sin \left(\varepsilon+\varphi_{1}\right)-\varphi_{1} \cos \left(\varepsilon+\varphi_{1}\right)\right) \\
x_{2}^{e v}\left(\varphi_{1}\right)=r_{b}\left(\cos \left(\varepsilon+\varphi_{1}\right)+\varphi_{1} \sin \left(\varepsilon+\varphi_{1}\right)\right)
\end{array}\right. \\
& \varepsilon=\frac{\pi}{2 z}-2 \frac{\xi}{z} \operatorname{tg} \alpha_{0}-i n v \alpha_{0}
\end{aligned}
$$

Megjegyezzük, hogy a lefejtés $\varphi$ és a geometriai felírás $\varphi_{1}$ paramétere között lineáris kapcsolat áll fenn.

Az (5), (9) és (12) kifejezések segítségével a kapcsolódási egyenlet a következő alakot ölti:

$$
\begin{aligned}
& \left(y_{1}^{C}+m \xi\right) \cos \left(u+\alpha_{0}\right)+ \\
& +\left(x_{1}^{C}+r_{0} \varphi\right) \sin \left(u+\alpha_{0}\right)=0
\end{aligned}
$$

A trigonometriai egyenlet teljes megoldása

$$
u(\varphi)=-\alpha_{0}-\operatorname{arctg} \frac{y_{1}^{C}+m \xi}{x_{1}^{C}+r_{0} \varphi}+k \pi, \quad k \in \mathbb{Z}
$$

A kapcsolódási egyenlet megoldása a lekerekítési ívhez tartozó teljes kör pontjaira vonatkozik; ezek közül ki kell emelni azokat a megoldásokat, amelyek a valós foglábgörbét jelentik. Jelöljük $\mathrm{g}(\varphi)$-vel az ívtangens argumentumát. Észre lehet venni, hogy a

$$
\varphi_{\text {krit }}=\frac{x_{1}^{C}}{r_{0}}
$$

értékre a függvénynek függőleges aszimptotája van. A valós burkológörbe, azaz a lábgörbe az 
$u(\varphi)=\left\{\begin{array}{l}-\arctan (g(\varphi))-\alpha_{0}+\pi, \text { if } \varphi \leq \varphi_{k r i t} \\ -\arctan (g(\varphi))-\alpha_{0}, \quad \text { if } \varphi>\varphi_{\text {krit }}\end{array}\right.$

paraméter-összefüggésre valósul meg.

\section{Numerikus szimuláció}

A foglábgörbe-egyenletek analitikus alakját a (6) mátrixegyenlet kifejtéséből kapjuk, ha az $\underline{\mathbf{r}}_{1}$ helyvektor koordinátáiban az $u$ paramétert a (16) függvénnyel helyettesítjük. Az egyenleteket, tekintettel bonyolult alakjukra, nem írjuk fel. $\mathrm{Az}$ analitikus eredményeket a Mathcad környezetben ellenőriztük, $z_{2}=18$ fogú, $m=5 \mathrm{~mm}$ modulú fogaskerékre.

A 3. ábrán a burkolt körsereg és a burkoló foglábgörbe látható, arra az esetre, amikor a relatív sugártényező $\psi=0,79$, ami $r=1,5 \mathrm{~mm}$ értékű sugárnak felel meg. A görbék geometriai viszonya és relatív helyzete arra enged következtetni, hogy minél kisebb a lekerekítési sugár, annál meredekebb, hegyesebb a foglábgörbe. Ezt különböző beállításokkal elkészített fogazatok grafikus összehasonlításával igazoljuk. Bár a klasszikus alámetszési elmélet szerint [7] az alámetszés határa $\xi=-0,053$, a generálást a $\xi €\{-0,15 ;-0,2 ;-0,25$;$0,3 ;-0,35 ;-0,4\}$ értékekre és $\psi=0,79$, illetve $\psi=0,1$ relatív lekerekítési sugarú szerszámmal végeztük el. Az eredményeket a 4., 5., 6., 7. és 8. ábrákon szemléltetjük.

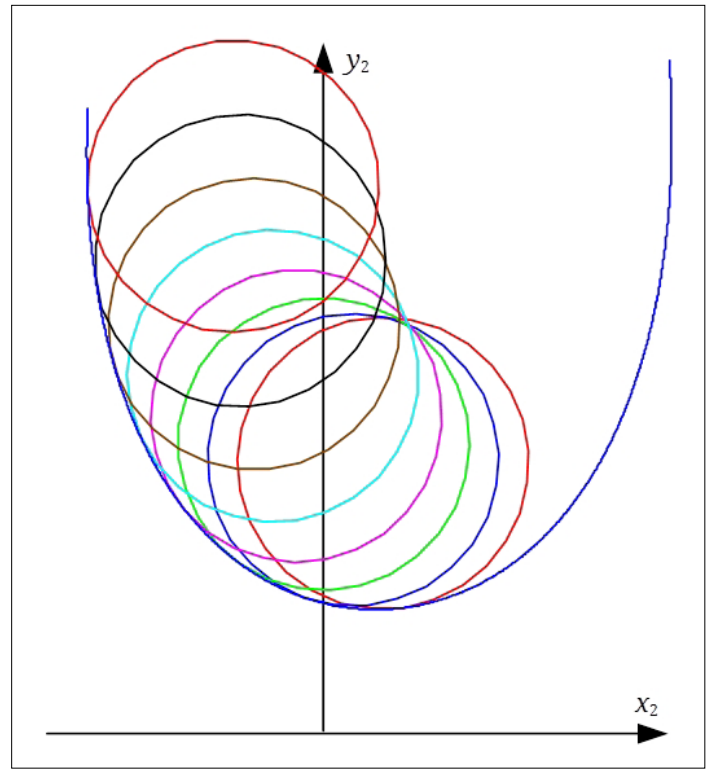

3. ábra. A foglábgörbe és a burkolt körsereg

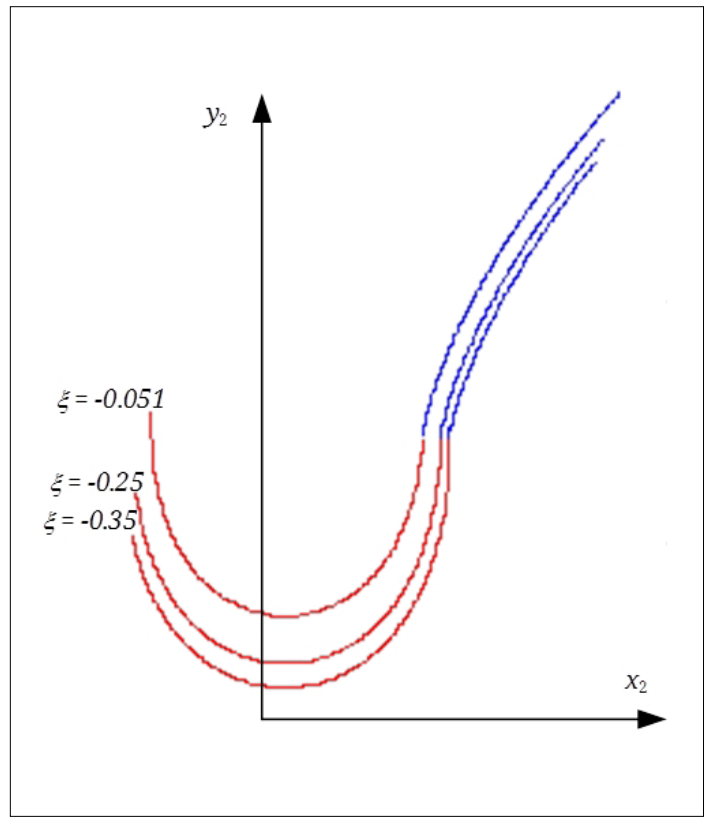

4. ábra. A foglábgörbe és az evolvens csatlakozása $r=1,5 \mathrm{~mm}$ lekerekítési sugarú szerszám használata esetén

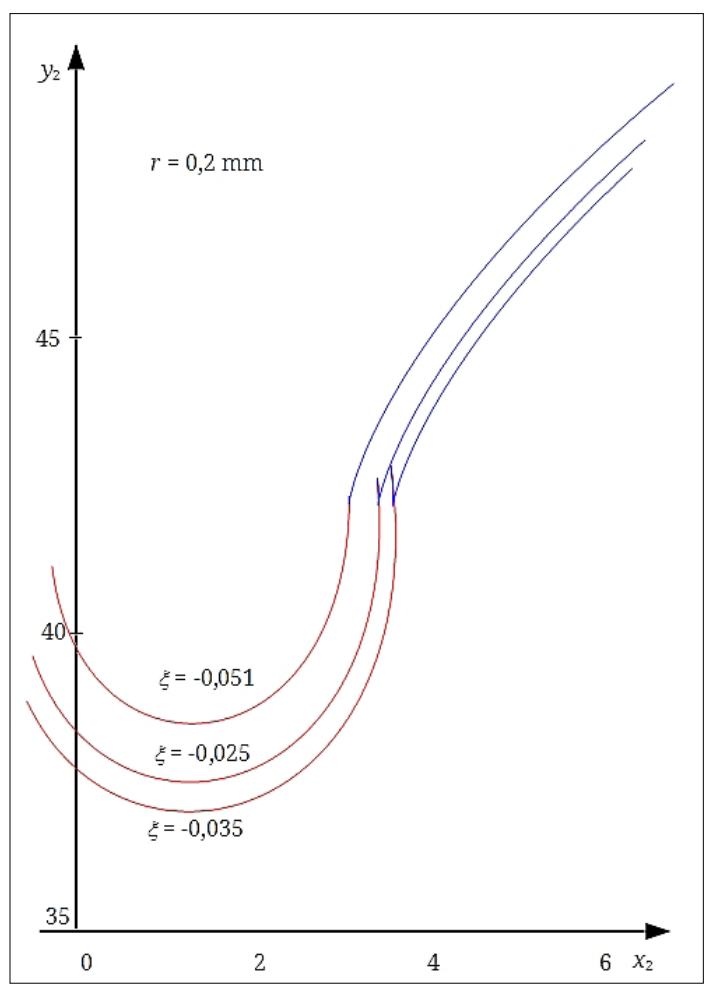

5. ábra. A foglábgörbe és az evolvens csatlakozása $r=0,2 \mathrm{~mm}$ lekerekítési sugarú szerszám használata esetén 


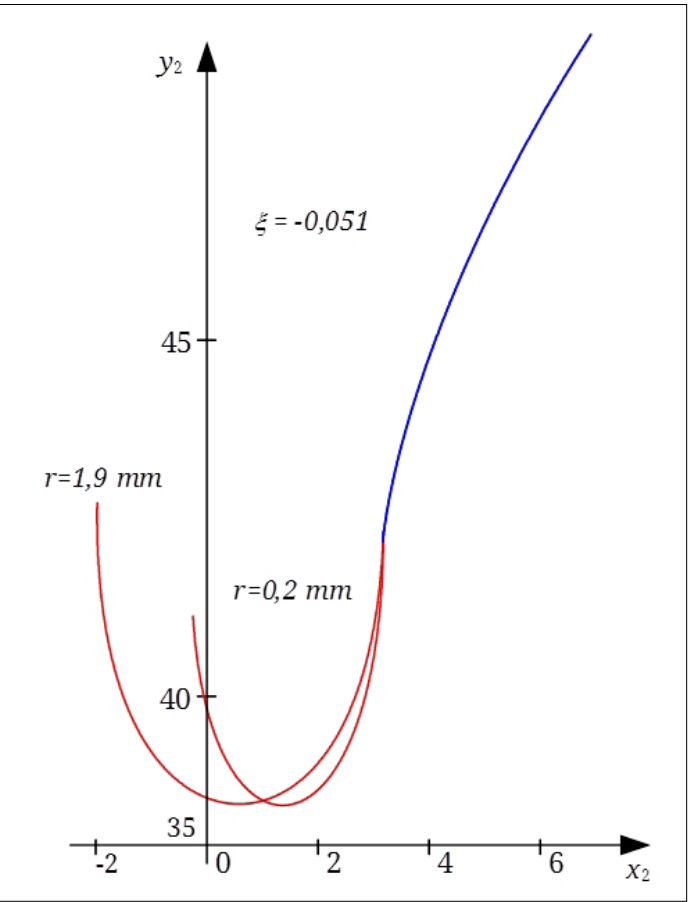

6. ábra. A foglábgörbe alakjának függése a lekerekítési sugártól - a klasszikus profileltolás határán

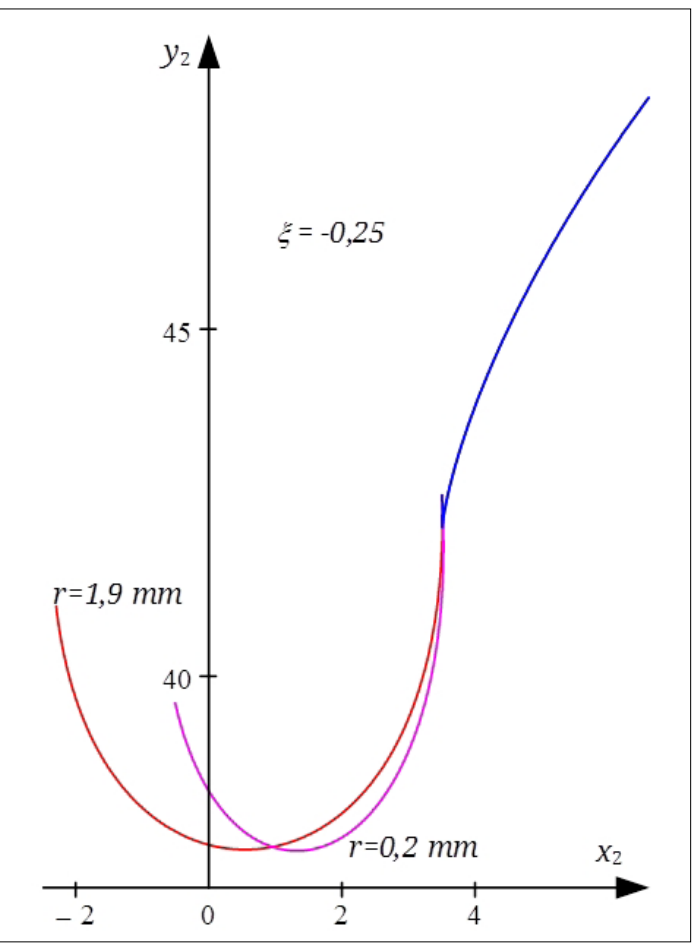

7. ábra. A foglábgörbe alakjának függése a lekerekítési sugártól: $\xi=-0,25$

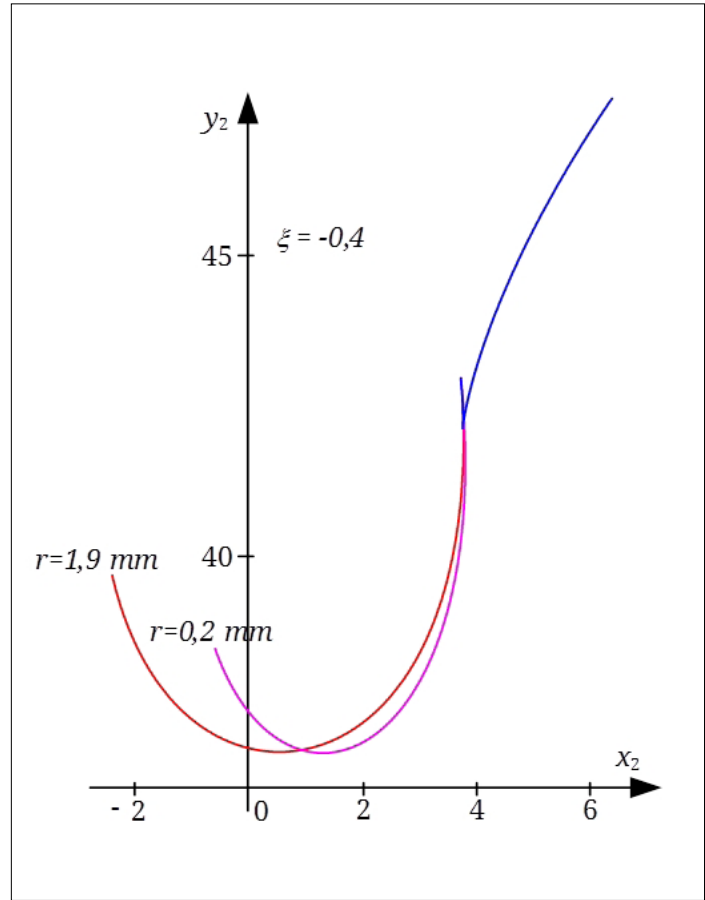

8. ábra. A foglábgörbe alakjának függése a lekerekítési sugártól: $\xi=-0,40$

A 4. ábrán jól látható, hogy megfelelő nagyságú lekerekítési sugár esetében az alámetszés nem jelentkezik olyan élesen, mint azt a szakirodalom [7] tárgyalja. Az is tény, hogy az evolvens szakasz, ami a mozgástörvény betartásáért felel, lényegesen rövidül, ami a kapcsolószámot jelentősen csökkenti. Viszont a fogtőben feszültségkoncentrátor nem keletkezik. Összehasonlításképpen vizsgáljuk meg az 5 . ábrán szemléltetett profilokat, ahol a klasszikus számításnak megfelelő alámetszés-határi profileltolás is csupán egy enyhe alámetszéshez vezet.

A 6., 7. és 8. ábrán jól észrevehető, hogy a lekerekítési sugár lényeges befolyást gyakorol a foglábgörbe alakjára. Nagyobb lekerekítési sugár esetében az alámetszés sokkal tompábban, elfogadható módon jelentkezik. Bár az evolvens profil rövidülése a kapcsolódás rovására megy, bizonyos esetekben előfordulhat, hogy az alámetszés klasszikus határa alá kell fogazni; ez esetben a lekerekítési sugár értékét lényeges meghatározni. A következőkben egy alternatív szintetikus geometriai módszert mutatunk be a szinguláris pontok azonosítására. 


\section{Az alámetszés geometriai modelle- zése}

A fogaskerék-kapcsolás elméletében lényeges áttörést Litvin hozott [2], aki az alámetszés határát a szinguláris pontoknak a burkoló profilon való megjelenése pillanatával azonosította. Elképzelése nagyszerü geometriai-kinematikai észrevétel, hiszen ez esetben a parametrikus alakban felírt görbének $\dot{x}, \dot{y}$ deriváltjai nullák, azaz a profil mentén való elmozdulási sebesség is nulla, ami a kapcsolódás törvényének ellentmond. Ennek alapján az abszolút sebességek kiegyenlítésének feltételét kiaknázva felírható, hogy

$$
\begin{aligned}
& \boldsymbol{v}_{t}^{(1)}+\boldsymbol{v}_{r}^{(1)}=\boldsymbol{v}_{t}^{(2)}+\boldsymbol{v}_{r}^{(2)} \Rightarrow \\
& \boldsymbol{v}_{r}^{(2)}=\boldsymbol{v}^{(12)}+\boldsymbol{v}_{r}^{(1)}
\end{aligned}
$$

A (17) egyenlet megengedi a szerszámprofil korlátozását, $\mathrm{a} \mathbf{v}_{\mathrm{r}}^{(2)}=0$, feltételből, anélkül, hogy a burkolóprofil egyenleteit kiszámítsuk.

A jelen közleményben javasolt szintetikus geometriai módszer lehetővé teszi az egyenletek felírását, anélkül, hogy a [2]-ben leírt módszer egyenletrendszerét kellene használni.

A teljes generáló görbe egyenes és görbe szakaszára külön szemléltetjük a geometriai összefüggéseket.

Tekintsük a 9. ábrát, ahol az egyenes profil tetszőleges pontjában megadott sebességeket ábrázoltuk.

Az alaphelyzetből $r_{0} \varphi$-vel eltolt lécprofil $M$ pontja lesz a kapcsolódási pont, mivel a rajta keresztül haladó profilnormális tartóegyenese megy át a $P$ főponton. A léc $\mathbf{v}_{\mathrm{t} 1}$ haladási sebességét felvesszük. Tudva azt, hogy az $M$ kapcsolódási pont pályája a kapcsolóegyenes, így az $M$-ben definiált abszolút

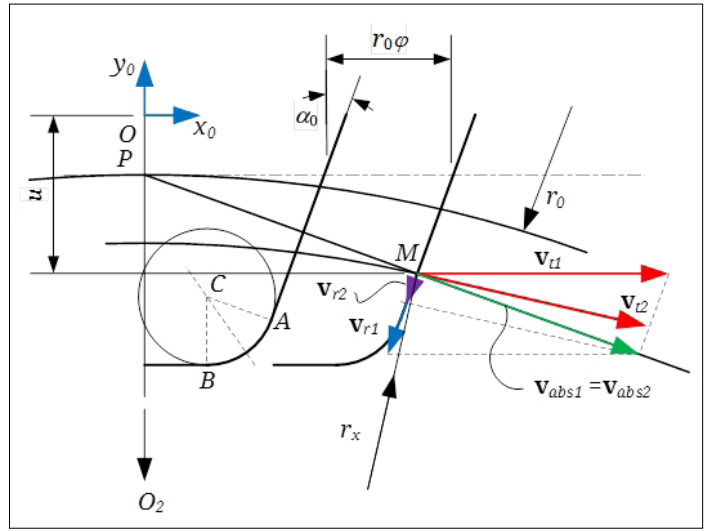

9. ábra. A sebességvektorok a generáló lécprofil egyenes szakaszán, a pillanatnyi kapcsolódási pontban sebességvektor is a kapcsolóegyenesre illeszkedik, valamint azt is, hogy a relatív sebességvektor a profilt kell érintse, a relatív sebesség értékét könnyen ki lehet számítani. Az álló koordináta-rendszerhez fel lehet írni, hogy

$$
\left(\begin{array}{l}
-v_{r 1} \sin \alpha_{0} \\
-v_{r 1} \cos \alpha_{0}
\end{array}\right)+\left(\begin{array}{c}
v_{t 1} \\
0
\end{array}\right)=\left(\begin{array}{c}
v_{a b s z} \cos \alpha_{0} \\
-v_{a b s z} \sin \alpha_{0}
\end{array}\right)
$$

A kifejtés és a számítások után kapjuk, hogy

$v_{r 1}=\frac{v_{t 1}}{\sin \alpha_{0}}$

Ezzel a $\mathbf{v}_{12}+\mathbf{v}_{\mathrm{r} 1}=0$ feltétel, figyelembe véve a (9) és (10) kifejezéseket, a következő alakot ölti:

$$
\left\{\begin{array}{c}
-(u+m \xi)-r_{0} \sin ^{2} \alpha_{0}=0 \\
\frac{\pi m}{4}+u \operatorname{tg} \alpha_{0}+r_{0} \varphi-r_{0} \sin \alpha_{0} \cos \alpha_{0}=0
\end{array}\right.
$$

A (20) egyenletrendszer első egyenletéből, adott profileltolás értékre, megkapjuk azt az $u$ paraméterértéket, amelyre az alámetszés határesete fennáll. Ha ezt az egyenletet a $\xi=0, u=-h_{0}^{*} m$ értékekre sajátosítjuk, az elemi fogazat alámetszési fogszámhatárát kapjuk [7]. A második egyenlet megadja azt a legördülési szögértéket, amire a szinguláris pont a burkolóprofilon megjelenik.

A körívszakasz pontjainak sebességviszonyait a 10. ábrán tüntettük fel.

A lécprofilú szerszámon az előbbiekben is rögzített balról jobbra irányú pozitív legördülési $\varphi$ szögnek megfelelően a $C_{1}$ pont abszcisszája

$$
x_{1}^{C_{1}}=x_{1}^{C}+r_{0} \varphi
$$

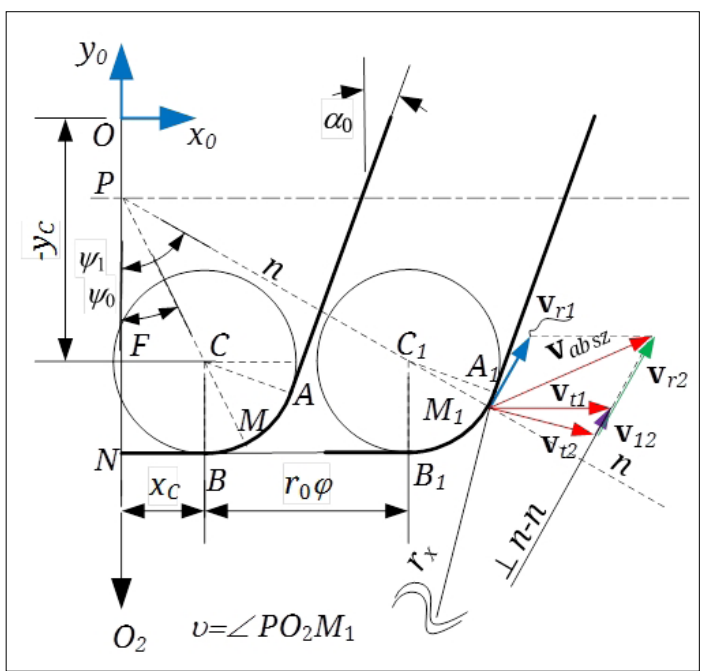

10. ábra. A sebességvektorok a generálóléc görbe szakaszán 
Ezzel, az $P F C_{1}$ háromszögből

$$
\operatorname{tg} \psi_{1}=\frac{x_{1}^{C}+r_{0} \varphi}{-y_{1}^{C}-m \xi}
$$

Ezzel, az $O_{2} M_{1}$ sugár és a tengelyvonal közötti $\vartheta$ szög értéke

$$
\operatorname{tg} \vartheta=\frac{x_{1}^{C}+r_{0} \varphi+r \sin \psi_{1}}{r_{0}+y_{1}^{C}+m \xi+r \sin \psi_{1}}
$$

Innen, az $O_{2} M_{1}$ sugár értéke, a $\vartheta(\phi)$ szög függvényében:

$$
O_{2} M_{1} \equiv r_{x}=\frac{x_{1}^{C}+r_{0} \varphi+r \sin \psi_{1}}{\sin \vartheta}
$$

A 2-es elem szállítósebessége a (23) és (24) kifejezések segítségével

$$
\underline{v}_{t 2}=\frac{r_{x}}{r_{0}}\left(\begin{array}{c}
\cos \vartheta \\
-\sin \vartheta \\
0
\end{array}\right)
$$

A következőkben föl kell írnunk a $v_{r 1}$ relatív sebesség értékét. A profil mentén a pontnak a helvzetét a $\psi_{1}$ szög változása határozza meg. $\mathrm{Az} \overparen{M M_{1}}$ ív elemi változása adja a relatív sebesség abszolút értékét:

$$
\begin{aligned}
& v_{r 1}=r \frac{d \psi_{1}}{d t}= \\
& \frac{-\left(y_{1}^{C}+m \xi\right) r_{0} \varphi}{\left(y_{1}^{C}+m \xi\right)^{2}+\left(x_{1}^{C}+r_{0} \varphi\right)^{2}} \omega_{2}, \omega_{2}=1 \frac{r a d}{s}
\end{aligned}
$$

Ezzel a 2-es kerék fogprofilján az érintkezési pont relatív sebessége

$$
\underline{v}_{r 2}=\left(\begin{array}{l}
r_{0} \\
0 \\
0
\end{array}\right)-\frac{r_{x}}{r_{0}}\left(\begin{array}{c}
\cos \vartheta \\
-\sin \vartheta \\
0
\end{array}\right)+v_{r 1}\left(\begin{array}{c}
\cos \psi_{1} \\
\sin \psi_{1} \\
0
\end{array}\right)
$$

Végül vegyük észre, hogy a körív $u$ paramétere és a legördülési $\varphi$ paramétertől függő $\psi_{1}$ paraméter között az alábbi reláció áll fenn:

$$
u=\frac{\pi}{2}-\alpha_{0}-\psi_{1}
$$

Ezzel, a (27) kifejezés első két elemét nullává téve, megkapjuk a szingularitást előidéző $u$ értéket, és azt a $\varphi$ legördülési szögértéket, amire a szinguláris pont megjelenik.

\section{Következtetések}

A lefejtőszerszám lekerekített része, ha a lekerekítési sugár megfelelő, sokkal előnyösebb foglábgörbét alakít ki, mint a hegyes elméleti szerszám.

A szimulációkból észre lehet venni, hogy a fogaskereket kisebb profileltolásra lehet fogazni, mint a klasszikus elmélet által előírt alámetszési határ.

A szinguláris pontok kialakulásának geometriai feltételei arra engednek következtetni, hogy a lekerekítési ív alakja lényegesen meghatározza a foglábgörbe alakját és a szinguláris pontok kialakulásának pillanatát.

\section{Köszönetnyilvánítás}

A szerzők ezúttal fejezik ki köszönetüket az Erdélyi Múzeum-Egyesületnek a kutatásban nyújtott segítségért, melynek részeredményeit jelen közleményben hozzuk nyilvánosságra.

\section{Szakirodalmi hivatkozások}

[1] Hollanda D.: Bazele așchierii și generării suprafețelor. Vol. 2. Editura Universității „Petru Maior” Tîrgu-Mureș, 1996. 160-162.

[2] Litvin F. L.: A fogaskerékkapcsolás elmélete. Müszaki Könyvkiadó, Budapest, 1972.

[3] Máté M.: Hengeres fogaskerekek gyártószerszámai. Erdélyi Múzeum-Egyesület, Kolozsvár, 2016. https://doi.org/10.36242/mtf-12

[4] Balajti Zs.: Examination and adjustment of the bearing pattern in case of helicoid drives. In: $8^{\text {th }}$ CIRP Conference on High Performance Cutting, Budapest, Hungary, June 25-27. 2018. Procedia CIRP. 77. (2018) 267-270.

[5] Mohammad Q. A., Muhsin J. J.: Analytical Solution of Bending Stress Equation for Symmetric and Asymmetric Involute Gear Teeth Shapes with and without Profile Correction. Innovative Systems Design and Engineering Vol. 3. Nr. 6. 2012 (2018). 19-30.

[6] Zhou Yuansheng, WuYuanhang, Wang Liming, Tang Jinyuan, Ouyang Hongwuab: A new closedform calculation of envelope surface for modelling face gears. In: Mechanism and Machine Theory, 137. (2019) 211-226.

[7] Szeniczei L.: Általános fogazás. Nehézipari Müszaki Könyvkiadó, Budapest, 1955.

[8] Radzewich S. P.: Gear Cutting Tools. CRC Press, NY. 2010. 